\title{
KAJIAN ANALISIS SWOT PADA INDUSTRI KONVEKSI DI CIPAYUNG DEPOK
}

\author{
Oleh: \\ Siti Marti’ah \\ Program Studi Teknik Informatika \\ Fakultas Teknik Matematika dan Ilmu Pengetahuan Alam \\ Universitas Indraprasta PGRI Jakarta \\ E-mail: \\ martia_setiadi@yahoo.co.id
}

\begin{abstract}
ABSTRAK
Kecamatan Cipayung Kota Depok merupakan daerah industri kecil yang membuat pakaian yang diperuntukkan mulai dari anak-anak sampai dengan dewasa. Tujuan kajian ini adalah untuk menganalisis dan mengevaluasi faktor-faktor internal dan eksternal yang mempengaruhi kelangsungan usaha dan menyusun strategi yang tepat dalam upaya pengembangan konveksi. Metode pengumpulan data dilakukan dengan cara pengamatan langsung dan wawancara. Data yang di peroleh dianalisis mengunakan faktor matrik Internal Factor Evaluation(IFE), External Factor Evaluation (EFE) Strenghts, Weaknesses, Opportunities, and Threats (SWOT) dan Quantitative Strategic Planning Matrix (QSPM). Hasil Identifikasi dan evaluasi strategi, diperoleh nilai IFE 2.710 dan EFE 2.782. Kedua perpaduan tersebut dalam matrik IE menunjukkan strategi pemasaran terletak pada kuadran lima, yaitu jaga dan pertahankan. Dari hasil analisis SWOT didapatkan alternatif strategi yang dapat diterapkan berdasarkan perhitungan matrik QSP, yaitu strategi pemasaran yang paling menarik untuk diterapkan yaitu mempertahankan ciri khas produk yang unik dan memperluas pangsa pasar di kota-kota besar Indonesia dengan memanfaatkan media promosi.
\end{abstract}

Kata Kunci: Strategi, SWOT, Konveksi, Depok

\section{A. PENDAHULUAN}

Kecamatan Cipayung adalah hasil pemekaran dari Kecamatan Pancoran Mas. Beberapa daerah seperti Pondok Terong, Bulak Timur, Bulak Barat merupakan daerah industri kecil konveksi atau sentra konveksi. Produk unggulan industri kecil ini adalah pakaian dalam, pakaian untuk segmen anak kecil hingga dewasa, dan celana ledging. Industri pembuatan pakaian ini biasanya dilakukan dengan sistem usaha perseorangan dan dalam pembuatannya dilakukan secara kekeluargaan. Setiap pengrajin atau konveksi yang membuat pakaian ini memiliki kemudahan dalam mendapatkan bahan baku utama, bahan penolong dan mesin pendukung yang relatif sederhana, serta tersedianya sumber daya manusia yang berpengalaman dalam memproses produksi pakaian dan celana. Hal ini menjadikan persaingan antar industri kecil yang satu dengan yang lain semakin ketat. 
Berdasarkan uraian-uraian di atas usaha industri kecil ini perlu menerapkan langkah-langkah yang strategik dalam memasarkan hasil produksinya agar dapat tetap bertahan dan mampu bersaing dalam menghadapi perubahan-perubahan lingkungan yang mendatang. Menurut pengamatan yang telah dilakukan tata kelola yang dilakukan oleh konveksi dalam menjalankan bisnisnya masih sangat sederhana dan tradisional, sehingga perlu dirumuskan strategi yang lebih komprehensif yang dapat dijadikan acuan dalam menjalankan bisnisnya lebih lanjut.

\section{B. KAJIAN PUSTAKA}

Manajemen strategis dapat didefinisikan sebagi suatu ilmu dan seni untuk memformulasi, mengimplementasi, dan mengevaluasi keputusan lintas fungsi yang memungkinkan organisasi dapat mencapai tujuannya (David, 2006). Tujuan manajemen strategis adalah untuk mengekploitasi dan menciptakan peluang baru yang berbeda untuk masa mendatang, perencanaan jangka panjang dan mengoptimalkan trend sekarang untuk masa datang.

Corak kegiatan pengembangan bisnis yang dilakukan dalam kegiatan perekonomian pasar ditentukan oleh interaksi antara pembeli dan penjual di pasar barang dan jasa. Interaksi ini akan menentukan corak kegiatan produksi yang akan dilakukan oleh perusahaan-perusahaan. Dalam interaksi penjual dan pembeli ini tidak terlepas dari permintaan dan penawaran, di mana sebuah barang tidak bisa diproduksi dan berapa jumlah yang harus diproduksi ini semua bisa ditentukan atau bisa dipecahkan dengan memperhatikan permintaan dan penawaran barang tersebut. Permintaan menerangkan tentang ciri hubungan antara jumlah permintaan dan harga (Sukirno, 2004). Terdapatnya permintaan belum merupakan syarat yang cukup untuk mewujudkan transaksi pasar. Permintaan yang wujud hanya dapat dipenuhi apabila penjual dapat menyediakan barang-barang yang diperlukan. Dalam hal ini komoditas tekstil yang ada dapat menyediakan bahanbahan yang diperlukan untuk pembuatan pakaian-pakain yang ditawarkan.

\section{METODE PENELITIAN}

Kajian ini dilakukan di konveksi Intan Collection yang berada di Cipayung Depok. Data yang digunakan terdiri dari data primer dan data sekunder yang bersifat kualitatif. Metode pengumpulan data dilakukan dengan cara observasi dan wawancara.

\section{HASIL DAN PEMBAHASAN}

Usaha konveksi ini adalah usaha yang berbentuk perseorangan dengan lokasi di Bulak Timur Cipayung Depok. Jenis pakaian yang dihasilkan beragam, mulai dari celana anak-anak, celana aladin, celana ledjing, celana arini, dan lainlain. Jumlah karyawan yang berkerja sebanyak 17 karyawan, terdiri dari 1 orang pemotong, 3 orang tenaga obras, 8 orang pejahit, 2 orang melipat dan mengemas, 2 orang bagian pengiriman, dan 1 orang bagian memasak (koki). Masa kerja karyawan rata-rata lebih dari 5 tahun. Pengadaan bahan baku diperoleh dari toko-toko yang ada di sekitar daerah Cipayung Depok. Apabila 
mengalami kesulitan bahan baku pemilik akan membeli di daerah Tanah Abang, Cipadu, Tangerang atau Bandung.

\section{Identifikasi Faktor-Faktor Strategi Internal dan Eksternal}

Hasil analisis dituangkan dalam Matrik IE untuk memetakan posisi perusahaan dan dengan matrik SWOT akan dirumuskan alternatif strategi yang dapat diimplementasikan sesuai dengan posisi usaha konveksi tersebut. Hasil identifikasi dan evaluasi faktor strategi internal yang berupa kekuatan dan kelemahan, serta faktor eksternal yang berupa peluang dan ancaman dapat di uraikan sebagai berikut:

Kekuatan: (1) mutu produk, (2) variasi produk, (3) pengalaman berwirausaha, (4) kapasitas produksi cukup besar, (5) loyalitas karyawan.

Kelemahan: (1) manajemen bersifat kekeluargaan, (2) kurangnya promosi, (3) tenaga pemasaran kurang optimal, (4) keterbatasan modal.

Peluang: (1) sumber bahan baku, (2) kemajuan teknologi, (3) regulasi undang-undang ukm, (4) kekuatan tawar menawar dengan konsumen, (5) kekuatan tawar menawar dengan pemasok.

Ancaman: (1) keberadaan usaha sejenis (2) perusahaan pendatang baru (3) keberadaan produk sejenis (4) suku bunga (5) kondisi ekonomi dan politik.

\section{Perumusan Strategi Matrik IFE dan EFE}

Dalam menganalisis matrik IFE dan EFE dilakukan terhadap faktor-faktor strategik lingkungan perusahaan, sehingga diperoleh faktor-faktor kunci yang termasuk dalam kekuatan, kelemahan, peluang dan ancaman perusahaan. Skor yang diperoleh dalam matrik ini menunjukkan kemampuan industri konveksi dalam memanfaatkan kekuatan dan mengatasi kelemahan yang dimiliki, serta menunjukkan kemampuan dalam meraih peluang dan mengatasi ancaman dalam masalah eksternalnya.

\section{Matrik IFE}

Dari hasil analisis faktor kunci internal dalam industri konveksi, yang menjadi kekuatan utama dalam usaha ini adalah mutu produk dengan bobot 0.200 dan rating 4.000 sehingga diperoleh skor 0.800. Adapun kelemahan utama dalam usaha konveksi ini adalah kurangnya promosi dengan bobot 0,022 dan rating 1,000 sehingga diperoleh skor 0,022 . Untuk lebih rinci hasil perhitungan faktor strategi internal dapat dilihat pada Tabel 1 di bawah ini : 
Tabel 1.

Matrik IFE Konveksi Intan Collection

\begin{tabular}{lccc}
\hline FAKTOR INTERNAL & BOBOT & RATING & SKOR \\
\hline Kekuatan (S) & & & \\
1. Mutu produk & 0.200 & 4.000 & 0.800 \\
2. Variasi Produk & 0.133 & 4.000 & 0.532 \\
3. Pengalaman berwirausaha & 0.111 & 3.000 & 0.333 \\
4. Kapasitas produksi cukup besar & 0.089 & 3.000 & 0.267 \\
5. Loyalitas Karyawan & 0.044 & 3.000 & 0.132 \\
Kelemahan (W) & & & \\
1. Manajemen bersifat kekeluargaan & 0.156 & 1.000 & 0.156 \\
2. Kurangnya promosi & 0.022 & 1.000 & 0.022 \\
3. Tenaga pemasaran yang belum optimal & 0.178 & 2.000 & 0.356 \\
4. Keterbatasan modal & 0.067 & 2.000 & 0.112 \\
Total & 1.000 & & 2.710 \\
\hline
\end{tabular}

Hasil analisis perhitungan faktor-faktor internal didapatkan total skor 2,710. Nilai ini berada di atas nilai rata-rata 2,50, menunjukkan posisi perusahaan cukup kuat. Usaha konveksi ini memiliki kemampuan di atas rata-rata dalam memanfaatkan kekuatan dan mengantisipasi kelemahan internal.

\section{Matrik EFE}

Kekuatan tawar menawar dari konsumen merupakan peluang utama, dalam hal ini mendapatkan bobot 0,164 dan rating 4.000, sehingga di peroleh skor 0,656. Sedangkan faktor yang menjadi ancaman utama perusahaan adalah keberadaaan usaha konveksi yang sama dengan bobot 0.182 dengan rating 2 sehingga di peroleh skor 0,364 (Tabel 2). Dari hasil analisis faktor strategi eksternal didapatkan skor matrik EFE 2,782. Nilai tersebut di atas nilai rata-rata 2.50, menunjukkan bahwa perusahaan memiliki strategi efektif untuk memanfaatkan peluang dan meminimalkan ancaman dan pengaruh negatif eksternal.

Tabel 2.

Matrik EFE Konveksi Intan Collection

\begin{tabular}{clll}
\hline FAKTOR EKSTERNAL & BOBOT & RATING & SKOR \\
\hline $\begin{array}{l}\text { Peluang } \\
\text { 1. Sumber Bahan Baku }\end{array}$ & 0.127 & 3 & 0.381 \\
2. Keunggulan Teknologi & 0.018 & 3 & 0.435 \\
3. Regulasi UU UKM & 0.091 & 3 & 0.219 \\
4. Kekuatan tawar menawar dari & 0.055 & 4 & 0.656 \\
konsumen & 0.036 & 3 & 0.327 \\
5. Kekuatan tawar menawar dari & & & \\
$\quad$ pemasok & & & \\
Ancaman & & & \\
1. Keberadaan perusahaan sejenis & 0.182 & 2 & 0.364 \\
2. Perusahaan pendatang baru & 0.018 & 2 & 0.036 \\
3. Keberadaan produk sejenis & 0.091 & 2 & 0.182 \\
4. Suku Bunga & 0.055 & 2 & 0.110 \\
5. Kondisi ekonomi dan politik & 0.036 & 2 & 0.072 \\
\hline Total & 1,000 & & 2,782 \\
\hline
\end{tabular}




\section{Matrik IE}

Matrik IE digunakan untuk menentukan posisi usaha yang didasarkan pada hasil analisis matrik IFE dan EFE. Pada hasil analisis konveksi Intan Collection, nilai total matrik IFE 2,710 dan nilai matrik EFE 2,782. Dengan demikian posisi usaha konveksi terletak pada kuadran V (lima), yaitu jaga dan pertahankan. Strategi yang diterapkan pada kuadran ini adalah penetrasi pasar, pengembangan produk dan pengembangan pasar (David, 2006). Selanjutnya hal ini digunakan untuk merumuskan alternatif strategi dengan menggunakan matrik SWOT. Posisi perusahaan berdasarkan pada matrik IE bisa di lihat pada Bagan 1 berikut ini :

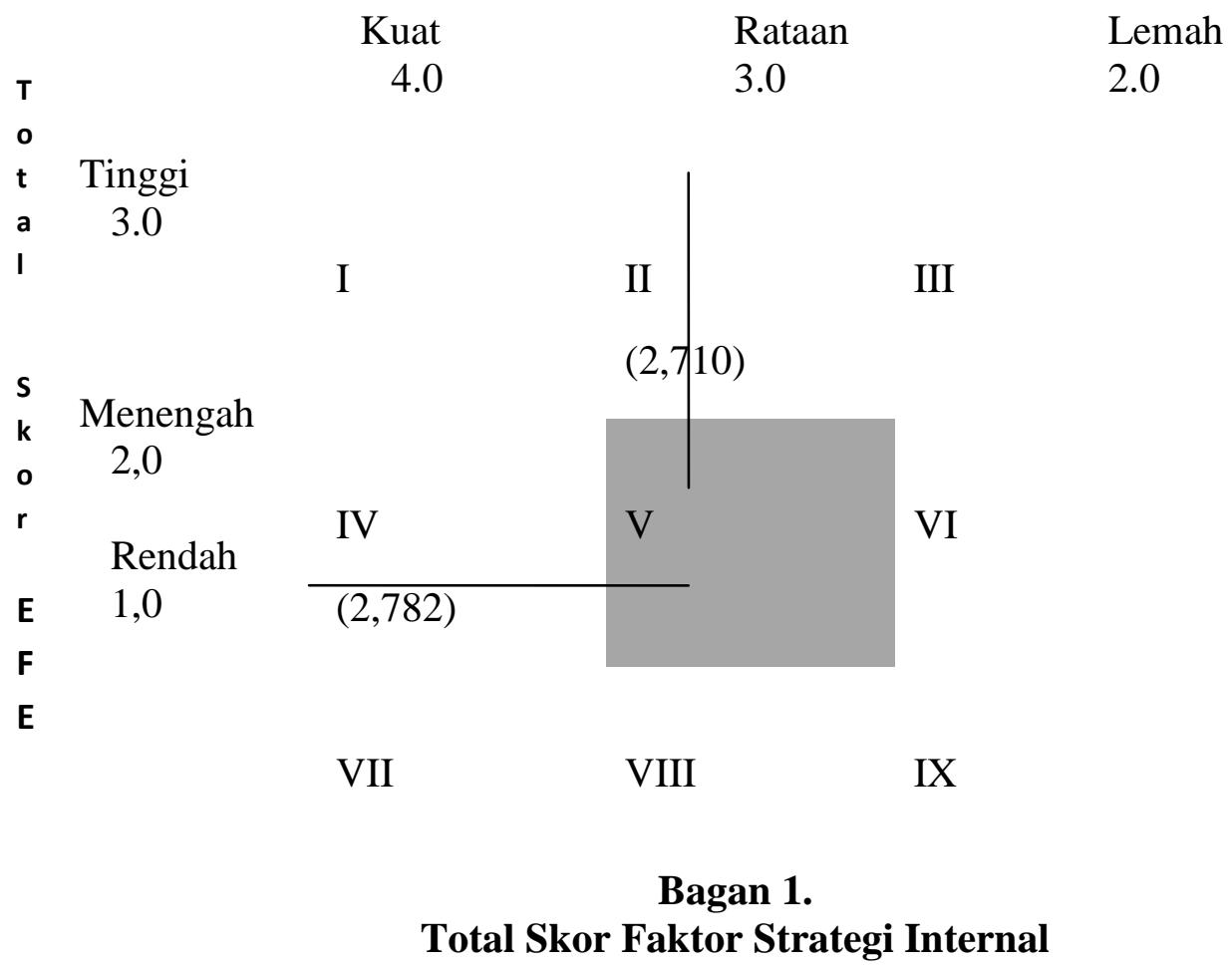

\section{Matrik SWOT}

Dalam penyusunan strategi pada matrik SWOT di sesuaikan dengan hasil yang di peroleh dari matrik IE, yaitu strategi penetrasi pasar, pengembangan pasar dan pengembangan produk. Untuk hasil analisis SWOT untuk konveksi Intan Colection bisa di lihat pada Bagan 2 di bawah ini : 


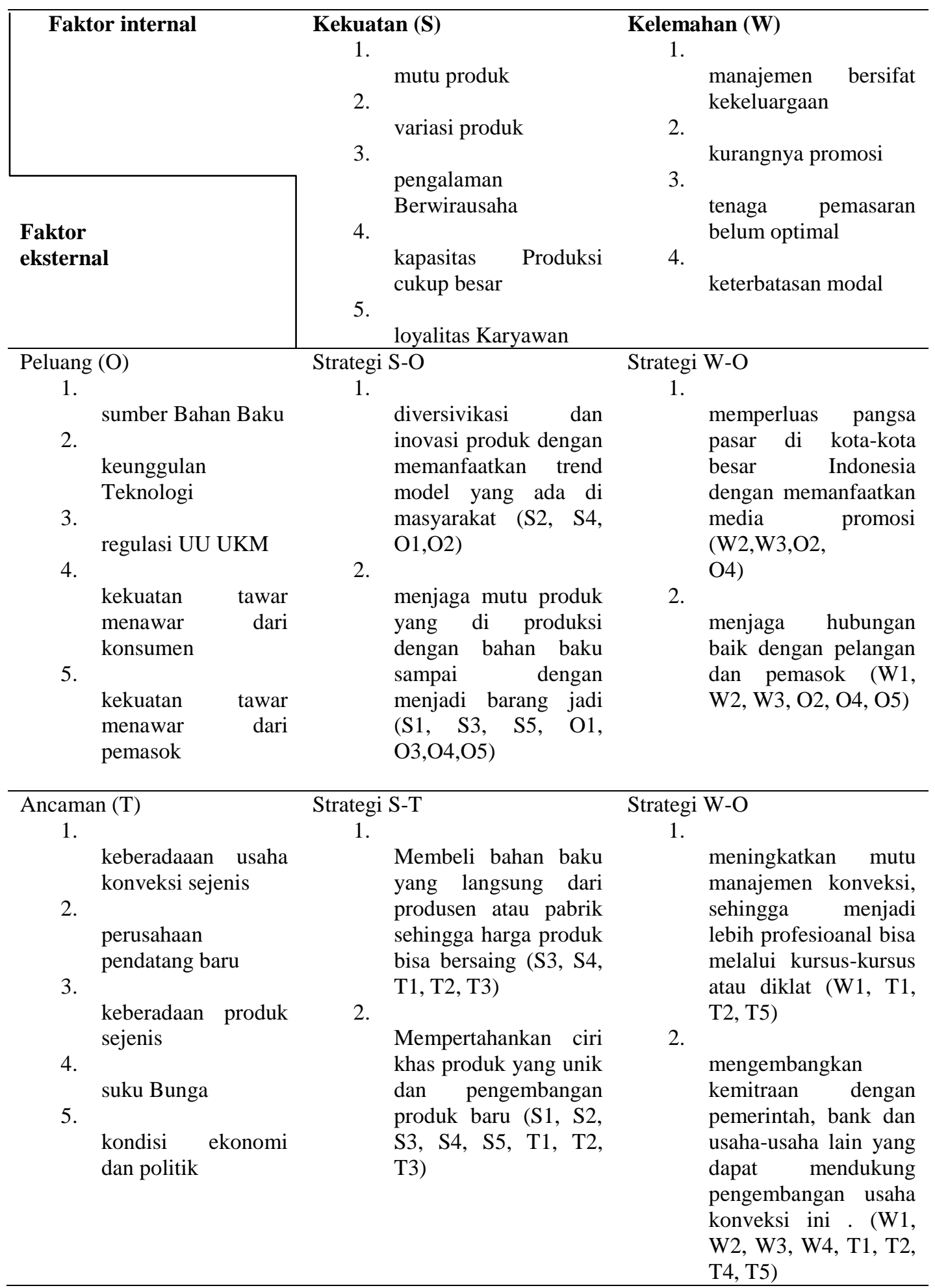

Bagan 2. Matrik SWOT 


\section{Analisis Matrik QSP}

Untuk mengevaluasi dan menganalisis secara objektif strategi yang dihasilkan dari matrik SWOT serta menentukan strategi prioritas yang bisa diimplementasikan, dilakukan dengan menggunakan matrik QSP. Dalam hal ini alternatif-alternatif strategi dibagi menjadi 3 kelompok yaitu aspek pemasaran, manajemen dan teknis produksi.

Pertama, aspek pemasaran yang terdiri dari (a) Diversifikasi dan inovasi produk dengan memanfaatkan beberapa model desain yang lagi trend dan di sukai masyarakat, (b) Memperluas pangsa pasar di kota-kota besar Indonesia dengan memanfaat media promosi yang ada. (c) Mempertahankan ciri khas produk yang unik walau banyak model pilihan.

Kedua, aspek manajemen yang terdiri dari (a) Menjaga hubungan baik dengan pelangan dengan pemasok, (b) Meningkatkan mutu produk dan manajemen sehingga lebih profesional, (c) Mengembangkan kemitraan dengan pemerintah, bank dan perusahaan lain yang dapat mendukung perkembangan konveksi Intan Collection.

Ketiga, aspek teknis produksi (a) Menjaga mutu produk yang diproduksi, (b) Membeli langsung bahan baku dari pabrik sehingga harga produk bisa bersaing.

Dari hasil perhitungan dalam matrik QSP, diperoleh strategi yang paling tepat untuk diimplementasikan dalam aspek pemasaran yaitu dengan memperluas pangsa pasar yang ada di kota-kota besar di Indonesia dengan memanfaatkan media promosi, diikuti dengan strategi diversifikasi dan inovasi produk dengan memanfaatkan model yang trend tapi tetap disukai masyarakat. Lebih jelas tentang urutan prioritas strategi dari hasil matrik QSP dapat dilihat dalam Tabel 3 berikut : 
Tabel 3.

Urutan Prioritas Strategi dari Matrik QSP Konveksi Intan Collection

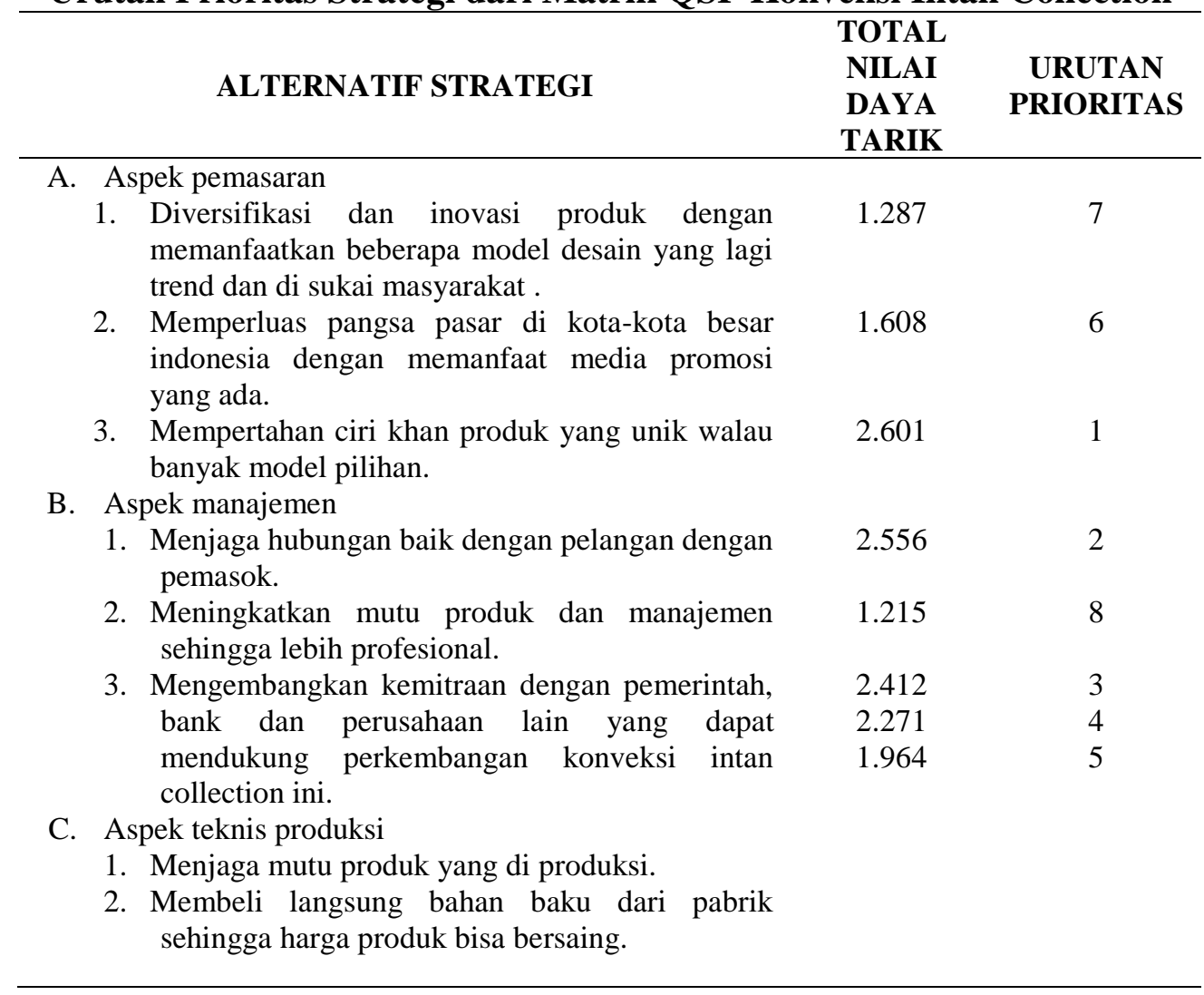

\section{Implikasi Manajerial}

Dalam kajian ini implikasi manajerial berkaitan dengan bauran pemasaran Product (produk), yaitu memberikan masukan kepada Intan Collection untuk memperbaiki mutu dan model pakaian konveksi. Diantaranya memberikan merk produk, informasi mengenai cara mencuci, dan pola potongan celana yang bagus dan nyaman di pakai.

Implikasi manajerial yang berkaitan dengan bauran pemasaran Price (harga), yaitu memberikan harga lebih rendah dari harga pesaing dan memberikan potongan harga pada konsumen yang memesan dalam jumlah besar, termasuk potongan harga pada hari-hari tertentu.

Implikasi manajemen yang berkaitan dengan bauran pemasaran Place (tempat atau saluran distribusi), yaitu selalu berusaha membuat ruangan yang nyaman, aman dan bersih untuk konsumen, tersedianya produk dalam jumlah yang cukup dan bervariatif, serta dapat memperpanjang waktu pelayanan terhadap konsumen untuk hari-hari tertentu di saat konveksi ramai pengunjung. Indikator pelayanan yang baik adalah kecepatan pelayanan, yaitu seberapa cepat waktu yang dibutuhkan untuk melayani konsumen hingga produk sampai di tangan konsumen (Hertina et al, 2009) 


\section{E. SIMPULAN}

Dilihat dari hasil identifikasi faktor internal dan faktor eksternal usaha konveksi Intan Collection menunjukkan posisi perusahaan pada kuadran lima, yaitu jaga dan pertahankan, dimana strategi yang bisa di jalankan adalah penetrasi pasar, pengembangan produk dan pasar. Dari hasil analisis SWOT didapatkan alternatif strategi yang dapat diterapkan. Berdasarkan perhitungan matrik QSP diperoleh strategi yang paling menarik untuk diterapkan, yaitu dari aspek pemasaran, diantaranya adalah mempertahankan ciri khas produk yang unik dan memperluas pangsa pasar di kota-kota besar Indonesia dengan memanfaatkan media promosi.

\section{DAFTAR PUSTAKA}

David, F.R. (2006). Manajemen Strategi (Terjemahan). Jakarta: PT. Prenhallindo Indonesia.

Hertina, Siska. (2009). Analisis Harapan dan Kepuasan Pasien Terhadap Mutu Pelayanan Kesehatan di Puskesmas Katasura II Tahun 2009. FKM. Universitas Muhammadiyah Surakarta. Diakses http://etd.epints.ums.ac.id/4018/1/J410070071.pdf tanggal 28 April 2015.

Sukirno, Sadono. (2004). Pengantar Teori Makroekonomi. Penerbit PT Raja Grafindo, Jakarta 